\title{
Manajemen Pembiayaan Bantuan Operasional Sekolah dalam Meningkatkan Mutu Pendidikan Madrasah Aliyah di Lingkungan Kantor Kementerian Agama Kota Surabaya
}

\author{
Ari Sandi Setiawan ${ }^{1}$, Ismet Basuki ${ }^{2}$, Erny Roesminingsih ${ }^{3}$ \\ ${ }^{123}$ Surabaya State University \\ Email: ari.19006@mhs.unesa.ac.id
}

\begin{abstract}
In the Indonesian education world system, education financing is a strategic element that will determine the attainment of the stated educational goals for registration. In other words, the quality of education practice in Indonesia is strongly influenced by the share of education financing. Because education cannot be separated from the use of funds or expenditures in the provision of education, educational institutions must prioritize the management of these costs so that they can be allocated according to their registration. This research is a qualitative descriptive study, using observation and interview methods, the data obtained to describe the process of allocating, monitoring, and evaluating education funds provided by the School Operational Assistance for the Ministry of Religion Surabaya Office to be distributed to madrasas in Surabaya. The results of this study indicate that the management of school operational assistance funding in the Ministry of Religion Office environment starting from the distribution of funding for school operational assistance funds at madrasah has been implemented as technical guidelines have been made, which in distribution must go through several stages such as making madrasah activity plans, making letters. a cooperation agreement, each distribution is carried out in two stages. Supervision of the financing of school operational assistance funds is carried out in direct and indirect ways, direct supervision is carried out to observe, inspect, check directly on work and receive reports of realization or supervision. Indirect supervision is carried out by looking at and checking again from the accountability report that has been made by the madrasah.
\end{abstract}

Keywords: Funding Management; Madrasah BOS; Education Quality.

Abstrak. Dalam sistem dunia pendidikan Indonesia, pembiayaan pendidikan merupakan elemen strategis yang akan menentukan pencapaian tujuan pendidikan tujuan pendaftaran yang telah ditetapkan. Dengan kata lain, kualitas praktik pendidikan di Indonesia sangat dipengaruhi oleh bagian pembiayaan pendidikan. Karena pendidikan tidak lepas dari penggunaan dana atau pengeluaran dalam penyelenggaraan pendidikan, maka lembaga pendidikan harus mengutamakan pengelolaan biaya tersebut agar dapat dialokasikan sesuai dengan pendapatan. Penelitian ini adalah penelitian deskriptif kualitatif, menggunakan metode observasi dan wawancara, data yang diperoleh untuk mendeskripsikan proses pengalokasian, pengawasan, dan evaluasi dana pendidikan yang disediakan oleh dana Bantuan Operasional Sekolah Kantor Kementerian Agama Surabaya untuk disalurkan untuk madrasah yang ada di Surabaya. Hasil penelitian ini menunjukkan bahwa manajemen pembiayaan bantuan operasional sekolah di lingkungan Kantor Kementerian Agama dimulai dari penyaluran pembiayaan dana bantuan operasional sekolah pada madrasah telah dilaksanakan seperti petunjuk teknis yang telah dibuat, yang mana dalam penyaluran harus melalui beberapa tahapan seperti pembuatan rencana kegiatan madrasah, pembuatan surat perjanjian kerjasama, pada setiap penyaluran dilaksanakan dua tahap. Pengawasan pembiayaan dana bantuan operasional sekolah dilakukan dengan cara langsung dan tidak langsung, pengawasan langsung dilakukan untuk mengamati, memeriksa, mengecek sendiri secara langsung pekerjaan dan menerima laporan dari realisasi atau pengawasan. Pengawasan tidak langsung dilakukan dengan cara melihat dan mengecek kembali dari laporan pertanggungjawaban yang telah dibuat oleh pihak madrasah. 
Kata Kunci: Manajemen Pembiayaan; BOS Madrasah; Mutu Pendidikan.

\section{PENDAHULUAN}

Dalam sistem pendidikan Indonesia, pembiayaan pendidikan merupakan elemen strategis yang akan menentukan pencapaian tujuan yang telah ditetapkan. Dengan kata lain, kualitas praktik pendidikan di Indonesia sangat dipengaruhi oleh bagian pembiayaan pendidikan . Biaya digunakan untuk menyediakan Gedung sekolah atau kampus dan fasilitas lainnya, untuk membayar guru atau dosen, untuk menyediakan kursus dan layanan lainnya. Salah satunya perguruan perguruan tinggi dalam pembangkitan sumber daya yang mumpuni di bidang manajemen. Karena pendidikan tidak lepas dari penggunaan dana atau pengeluaran biaya tersebut agar dapat dialokasikan sesuai dengan pendapatan dan kebutuhan.

Menurut Soetjipto (1992: 31) pengelolaan keuangan meliputi kegiatan perencanaan, penggunaan atau pemanfaatan, pencatatan data, pelaporan dan pertanggungjawaban yang dialokasikan untuk menyelenggarakan sekolah dengan tujuan untuk menunjukkan tertib administrasi keuangan sehingga pengurusanya dapat dipertanggungjawabkan sesuai ketentuan yang berlaku. Dana BOS yang diberikan untuk sekolah juga perlu dikelola dengan baik. Menurut "Petunjuk Teknis Dana BOS Tahun 2012" Bantuan Operasional Sekolah (BOS) adalah program pemerintah yang pada dasarnya adalah untuk penyediaan pendanaan biaya operasi nonpersonalia bagi satuan pendidikan dasar sebagai pelaksanaan program wajib belajar. Salah satu yang mempengaruhi keberhasilan program BOS adalah pengelolaan dana dan segala sumberdaya yang ada dalam program BOS. Pentingnya pengelolaan dana BOS yaitu dengan pengelolaan yang baik akan mampu membantu ketercapaian tujuan dari program BOS dengan efektif dan efisien.

Salah satu bentuk pertanggungjawaban dalam pelaksanaan progeam BOS di madrasah adalah setiap pengelola harus melaporkan hasil kegiatannya kepada pihak terkait yaitu Dinas Pendidikan Agama Islam Kementerian Agama. Secara umum, situasi yang dilaporkan oleh pelaksana program terkait dengan statistik penerimaan bantuan, penyaluran, penyerapan dan penggunaan dana serta pengadaan tentang masalah terkait.

Penggunaan dana BOS sepenuhnya menjadi tanggung jawab instansi, kegiatan instansi antara lain pencatatan penerimaan dan pengeluaran dana dan laporan keuangan, sehingga memudahkan pemantauan penggunaan dana. Sebagai sistem pertanggungjawaban pelaksanaan rencana BOS, pengelolaan perencanaan di setiap tingkat (pusat, provinsi, kabupaten/kota sekolah) harus melaporkan hasil kegiatannya kepada pihak terkait. Secara umum, situasi yang dilaporkan oleh pelaksana program terkait dengan data statistic terkait penerima bantuan, penyaluran, penyerapan, penggunaan dana, pertanggungjawaban keuangan, serta hasil monitoring dan evaluasi serta pengaduan masalah.

Definisi follet yang dikutip oleh (Wijayanti, 2008)) Manajemen adalah seni menyelesaikan pekerjaan melalui manusia lain. Menurut Stoner, (Wijayanti, 2008: 1)) dikutip manajemen Apakah perencanaan, pengorganisasian, pembinaan dan Pantau pekerjaan dan penggunaan sumber daya anggota organisasi Sumber daya manusia organisasi lain untuk mencapai tujuan Organisasi yang ditentukan. Gulick dalam (Wijayanti, 2008: 1)mendefinisikan manajemen Sebagai upaya Memahami secara sistematis mengapa dan bagaimana manusia bekerja Untuk mencapai tujuan bersama dan membuat sistem lebih sempurna Bermanfaat bagi umat manusia. (Schein, 2008: 2) mendefinisikan manajemen sebagai sebuah profesi. Menurutnya, manajemen adalah kebutuhan Bekerja secara profesional, itu bercirikan profesionalisme Buat keputusan berdasarkan prinsip umum, profesional Dapatkan statusnya karena memenuhi standar prestasi kerja Tentu saja, para profesional harus ditentukan oleh kode etik yang ketat. (Terry, 2005: 1)) mendefinisikan manajemen sebagai suatu proses Atau kerangka kerja yang melibatkan bimbingan atau sumbangan Sekelompok orang dengan tujuan yang terorganisir atau nyata. Apakah pengetahuan itu Lakukan, definisikan lakukan, pahami Apa yang harus mereka lakukan dan mengukur efektivitasnya darinya Upaya dilakukan. Hal 
tersebut dapat disimpulkan dari beberapa definisi yang disebutkan di atas Manajemen adalah perusahaan patungan Tentukan dan capai tujuan organisasi Fungsi rencana pelaksanaan (rencana), organisasi (Organisasi), implementasi (pelaksanaan) dan pengawasan (kontrol). Manajemen adalah suatu aktivitas; disebut realisasinya Manajer dan orang yang melakukan pekerjaan ini disebut manajer. Setidaknya diperlukan manajemen untuk mencapai tujuan, Menjaga keseimbangan antara tujuan yang saling bertentangan, Dan mencapai efisiensi dan manfaat. Manajemen terdiri dari 7 berbagai unsur, yakni man, money, method, machine, market, material dan information.

Manajemen pembiayaan pendidikan adalah segenap kegiatan yang berkaitan dengan penataan sumber, penggunaan, dan pertanggungjawaban dana pendidikan di sekolah atau lembaga pendidikan. Kegiatan yang ada dalam manajemen pembiayaan meliputi tiga hal, yaitu penyusunan anggaran (budgeting), pembukuan (accounting), pemeriksaan (controlling). Sebagaimana yang tertuang dalam PP No. 48 Tahun 2003 tentang pengelolaan dana pendidikan, pengelolaan dana pendidikan meski berdasarkan pada konsep keadilan, efisiensi, transparansi dan akuntabilitas public (Depag RI, 2006:31). Menurut Soeryani, dalam bukunya (Sulistyorini, 2009) memaparkan bahwa definisi manajemen keuangan terdapat dua arti yaitu arti sempit dan arti luas, arti sempit tata pembukuan adapun arti luas berarti pertanggungjawaban dan pengurusan dalam penggunaan keuangan dalam skala pemerintahan pusat maupun daerah.

Dedi (Supriadi, 2010: 3) menjelaskan bahwa biaya pendidikan merupakan komponen yang memiliki peranan penting dalam mencapai tujuan pendidikan baik tujuan kuantitatif maupun kualitatif maupun kualitatif. Peranan biaya tidak dapat diabaikan, sehingga dapat dikatakan tanpa biaya proses pendidikan tidak akan berjalan. Maka dapat disimpulkan bahwa manajemen pembiayaan pendidikan adalah suatu proses kerja sama antara individu dengan kelompok serta dalam pengelolaan pembiayaan pada setiap kegiatan pendidikan dalam upaya mencapai tujuan pendidikan.

Dengan adanya kegiatan pengelolaan keuangan, dimungkinkan untuk merencanakan, membeli, dan mencatat secara transparan kebutuhan dana dalam setiap kegiatan pendidikan, dan menggunakannya untuk pelaksanaan program pendidikan yang efektif dan efisien. Terdapat 3 tujuan pengelolaan menurut Suryosubroto (Suryobroto, 2004: 86) adalah a) Meningkatkan efektivitas dan efisiensi penggunaan keuangan. b) Meningkatkan akuntabilitas transparansi keuangan. c) Meminimalkan penyalahgunaan anggaran. Dari 3 tujuan yang dijelaskan diatas tercapai maka pimpinan atau kepala instansi dituntut untuk berinovasi dalam menggali sumber dana, memilih bendahara yang berkompeten dalam bidang akuntansi dan akuntabilitas keuangan, serta menggunakan dana tersebut dengan efisien dan sesuai dengan perundang-undangan yang berlaku.

Perencanaan anggaran pendidikan ditinjau dari arti katanya perencanaan yang memiliki arti rencana, rancangan, dan niat. Perencanaan menurut Saefullah (Saefullah, 2012: 211) merupakan proses perencanaan kegiatan yang berkaitan dengan usaha membuat program yang di dalamnya memuat segala sesuatu yang akan dilaksanakan, penentu tujuan, arahan yang akan ditempuh, prosedur dan metode yang akan diikuti dalam pencapaian tujuan. Jika dikaitkan dengan keuangan, perencanaan adalah perencanaan sumber dana pendukung kegiatan pendidikan dan mencapai tujuan pendidikan. Suatu perencanaan dapat mengumpulkan banyak sumber daya agar dapat mencapai target dan tujuan suatu anggaran, yaitu dana untuk mengubah rencana menjadi berbagai komponen pendidikan. Perlu diperhatikan bahwa dalam rencana keuangan pendidikan antara lain menganalisis kegiatan dan prioritas yang direncanakan, serta menganalisis dana yang ada dari berbagai sumber pendapatan. Merumuskan rencana yang efektif dan efisien haruslah melibatkan semua aspek dan komponen institusi pendidikan agar mencapai tujuan peningkatan mutu pendidikan dengan tepat.

Dalam pikiran banyak orang, kualitas atau mutu memiliki banyak arti, semua itu tergantung siapa yang memakainya. Dalam kamus bahasa Inggris kualitas atau mutu adalah quality. Kata ini berasal dari bahasa latin quality yang memiliki arti secara harfiah. Berikut beberapa konsep yang didefinisikan beberapa ahli. 
Menurut Crosby, kualitas atau mutu adalah conformance to requirement (penerapan beberapa hal yang dibutuhkan). Produk berkualitas atau produk bermutu (jika ada) memenuhi standar kualitas yang ditentukan. Standar mutu mencakup elemen material bahan baku, proses produksi dan produksi jadi (Haris \& Nuryanti, 2010)

Dalam pengertian pendidikan, pengertian mutu meliputi masukan, proses dan atau Output pendidikan (Depdiknas, 2001). Suatu mutu baik untuk pendidikan karena meningkatkan rasa tanggung jawab sekolah atau kepada masyarakat dan atau pemerintah yang telah memberikan semua biaya ke sekolah dapat menjamin kualitas lulusan, dapat bekerja lebih profesional dan meningkatkan persaingan secara sehat (Husaini, 2009). Berdasarkan pandangan di atas dapat disimpulkan bahwa mutu pendidikan adalah kualitas atau ukuran dari proses perubahan sikap baik atau buruk dan tingkah laku individu atau kelompok menjadi manusia dewasa lebih dekat dengan Tuhan melalui konseling dan pelatihan. Mutu dalam pendidikan termasuk input dan output. Suatu input dikatakan bermutu apabila telah siap untuk berproses, dan proses bias dikatakan bermutu apabila mampu menghasilkan output atau lulusan yang berkompeten.

\section{METODE}

Metode penelitian yang digunakan dalam penelitian ini adalah metode deskriptif analisis dengan menggunakan pendekatan kualitatif, yaitu suatu metode penelitian untuk mengungkapkan gambaran yang jelas mengenai keadaan di kantor Kementerian Agama Kota Surabaya berdasarkan data yang diperoleh, dengan cara mengumpulkan dan menganalisis data tersebut dan mengubahnya menjadi informasi baru. Bogdon dan Taylor menyatakan bahwa "Metode kualitatif merupakan prosedur yang menghasilkan data deskriptif berupa katakata tertulis atau lisan dari orang-orang atau perilaku yang diminati, pendekatannya diarahkan pada latar dan individu secara holistic (utuh)” (Moleong, 2002: 3). Teknik pengumpulan data dilakukan melalui penelitian kepustakaan dan penelitian lapangan, yang terdiri dari wawancara dan observasi lapangan.
Pemilihan metode ini juga didasarkan kepada alasan bahwa penelitian ini bertujuan untuk dapat menjelaskan dan menggambarkan tentang manajemen pembiayaan bantuan operasional sekolah dalam meningkatkan mutu madrasah aliyah di lingkungan Kementerian Agama Kota Surabaya.

\section{HASIL DAN PEMBAHASAN}

\section{A. Penyaluran Pembiayaan Dana Bantuan Operasional Pada Madrasah Aliyah di Lingkungan Kantor Kementerian Agama kota Surabaya}

Dalam Lembaga pemerintahan pastinya terdapat bagian masing-masing dan setiap bagian juga memiliki jobdesk yang berfungsi menjalankan program kerja yang telah dibuat, sama halnya Kantor Kementerian Agama Kota Surabaya yang memiliki banyak bagian, salah satunya adalah seksi Penm. Pada bagian penma setiap karyawan memiliki jobdesk masingmasing, salah satu staf memegang bagian terkait program BOS diberikan kepada sekolah atau madrasah. Bantuan dana tersebut berasal dari DIPA dan dana ini harus dialokasikan kepada masyarakat agar meningkatkan kesejahteraan dan mutu bagi penerimanya. Dana DIPA tersebut didistribusikan oleh PD Penma melalui program dana Bantuan Operasional Sekolah pada madrasah.

Penyaluran dana BOS pada sekolah atau madrasah memiliki alur, baik dari pihak Kantor Kementerian Agama Surabaya maupun pihak sekolah. Alur yang harus ditempuh untuk proses penyaluran dana BOS pada sekolah atau madrasah adalah:

1) Mekanisme pencairan dana BOS untuk madrasah swasta menggunakan mekanisme pembayaran langsung (LS) dalam bentuk uang kepada sekolah atau madrasah melalui Kantor Pelayanan Perbendaharaan Negara (KPPN). Pencairan dana BOS dengan mekanisme pembayaran langsung dilakukan melalui dua tahap.

2) PPK menerbitkan Surat Perintah Pembayaran (SPP) setelah semua syarat penyaluran dana BOS sudah lengkap.

3) PPSM menerbitkan Surat Perintah Membayar (SPM) yang dilakukan kepada 
KPPN berdasarkan pengajuan SPP dari PPK.

4) Dalam hal penyampaian laporan pertanggungjawaban dana BOS dari sekolah atau madrasah sesuai dengan Surat Perjanjian Kerjasama setelah pekerjaan selesai atau pada akhir tahun anggaran.

Dalam realisasinya ada beberapa perbedaan dalam jumlah nominal yang diberikan pada tiap sekolah atau madrasah karena menyesuaikan dengan Rencana Kegiatan dan Anggaran Madrasah (RKAM) dan jumlah siswa pada setiap sekolah atau madrasah. RKAM ini berasal ini berasal dari bagian manajemen yaitu Planning berasal dari kata plan yang artinya rencana, rancangan maksud, dan niat. Perencanaan merupakan kegiatan yang berkaitan dengan usaha merumuskan program yang didalamnya memuat segala sesuatu yang akan dilaksanakan, penentuan tujuan, prosedur dan juga metode yang akan diikuti dalam pencapaian tujuan (Saefullah, 2012).

Hasil penelitian ini menunjukkan bahwa penyaluran pembiayaan dana Bantuan Operasional Sekolah (BOS) kepada sekolah atau madrasah di Kantor Kementerian Agama Surabaya telah dilakukan sesuai dengang juknis yang sudah dibuat. . Hal ini sesuai dengan pendapat dari Mulyono (Mulyono, 2010) bahwa pelaksanaan penyaluran dan pengelolaan dana Bantuan Operasional Sekolah wajib berpedoman pada Buku Panduan Pelaksanaan Bantuan Operasional Sekolah yang diterbitkan setiap tahun oleh Departemen Pendidikan Nasional dan Departemen Agama sebagai departemen teknis yang bertanggung jawab dalam pelaksanaan dan pengelolaan program tersebut.

Pengawasan dana Bantuan Operasional Sekolah dilakukan secara 2 tahap yakni pengawasan secara langsung dan pengawasan tidak langsung. Pengawasan secara langsung adalah tindakan pengawasan yang dilakukan secara pribadi oleh pimpinan dan pengawas yang ada pada PD Penma, dengan cara mengamati, meneliti, memeriksa, mengecek sendiri secara langsung. PD Penma mendatangi secara langsung dengan pengawas ke madrasah penerima bantuan melihat realisasi dari bantuan yang diberikan dan mengecek, menganalisis perincian yg sudah terealisasi. Pengawasan tidak langsung yang dilakukan oleh PD Penma yaitu mempelajari laporan yg sudah dibuat oleh sekolah penerima bantuan baik secara lisan maupun dokumen laporan pertanggungjawaban.

$$
\text { Laporan atau dokumen }
$$

pertanggungjawaban atas perincian yang sudah terealisasi yang dilakukan maupun segala aktivitas yang dilakukan oleh pihak penerima bantuan. Pemeriksaan anggaran atau pengawasan anggaran pada dasarnya adalah kegiatan menilai baik catatan dan menentukan prosedur dalam mengimplementasikan anggaran apakah sesuai dengan peraturan, kebijakan, dan standar-standar yang berlaku (Fattah, 2004)

\section{B. Pengawasan Pembiayaan Dana Bantuan Operasional Sekolah pada Madrasah di Kantor Kementerian Agama Kota Surabaya}

Dana Bantuan Operasional Sekolah dapat meningkatkan hasil belajar siswa, yang dilihat dengan prestasi yang diraih siswa, seperti yang dinyatakan oleh Crosby: mutu adalah kesesuaian sesuatu dengan hal-hal yang disyaratkan. Suatu produk dapat dikatakan bermutu jika sesuai dengan standar kriteria mutu yang ditentukan. Standar mutu tersebut meliputi anasir bahan baku, proses produksi, dan produk jadi.

Dalam peningkatan mutu pendidikan di madrasah aliyah dapat dilihat dari fasilitas yang diberikan kepada siswa dan juga proses dalam setiap pembelajarannya, dengan fasilitas yang dirasa memadai bagi para siswa, maka akan menghasilkan output atau produk yang sesuai dengan diharapkan. Seperti halnya dengan Madrasah Aliyah At Tauhid Surabaya dengan fasilitas pembelajaran yang dimilikinya mampu membangun semangat siswa dalam belajar sehingga mampu mencetak prestasi yang luar biasa.

Dana BOS dapat dibelanjakan oleh lembaga untuk berbagai keperluan penyelenggaraan pendidikan seperti gaji guru, peningkatan profesional guru, alat tulis kantor (ATK), kegiatan ekstrakurikuler, kegiatan pengelolaan pendidikan, juga supervisi pendidikan (Mulyono, 2010). Oleh karena itu di setiap pondok menggunakan dana tersebut untuk untuk meningkatkan semangat bagi para guru dalam mendidik para santri. Hal tersebut 
termasuk biaya personalia yang terdiri dari gaji pendidik dan tenaga kependidikan serta tunjangan yang melekat pada gaji (Mulyono, 2010). Dengan adanya honor atau tunjangan yang diberikan kepada guru/ustadz maka akan memiliki tanggung jawab dan semangat dalam menjalankan tugas yang diemban, karena guru bertugas untuk mendidik peserta didik atau siswa.

\section{KESIMPULAN}

Penyaluran pembiayaan dana Bantuan Operasional Sekolah pada Madrasah telah dilaksanakan seperti petunjuk teknis yang telah dibuat, yang mana dalam penyaluran harus melalui tahapan-tahapan seperti pembuatan Rencana Kegiatan Anggaran Madrasah, pembuatan surat perjanjian kerjasama, pada setiap penyaluran dilakukan dua tahap, setiap tahapan sebesar 50\% dari keseluruhan dana.

Pengawasan pembiayaan dana Bantuan Operasional Sekolah dilakukan dengan cara langsung dan tidak langsung, pengawasan langsung dilakukan untuk mengamati, memeriksa, mengecek sendiri secara langsung pekerjaan dan menerima secara langsung laporan dari pengawasan. Pengawasan tidak langsung dilakukan dengan cara melihat dan mengecek kembali dari laporan pertanggung jawaban yang telah dibuat oleh pihak Madrasah.

Implikasi dari pembiayaan dana Bantuan Operasional Sekolah dapat dirasakan dari peningkatan hasil belajar siswa yang berupa prestasi siswa tersebut, prestasi dapat didapatkan karena adanya fasilitas pembelajaran yang cukup sehingga dapat mendorong semangat dan motivasi belajar siswa, dengan adanya dana Bantuan Operasional Sekolah pada madrasah dapat meningkatkan semangat mengajar para guru..

\section{SARAN}

Kepada pihak PD Penma Kantor Kementerian Agama Surabaya diharapkan untuk terus memantau dan mengawasi penyaluran dana Bantuan Operasional Sekolah di tingkat madrasah, supaya bantuan tersebut benar-benar tersalurkan kepada yang berhak menerima dan dapat meningkatk an mutu pendidikan, baik mutu siswa, guru, dan sarana prasarana.
Kepada pihak sekolah mengharapkan dana Bantuan Operasional Sekolah digubakan dan dimanfaatkan dengan baik dan benar agar mutu pendidikan madrasah semakin meningkat.

Bagi peneliti lanjutan diharapkan hasil penelitian in dapat dijadikan refrensi atau rujukan, serta diharapkan untuk dilakukan penelitian lebih lanjut serta mendalam mengenai pengelolaan dana Bantuan Operasional Sekolah pada madrasah yang dirasa masih perlu perbaikan dan pembaruan penelitian yang berkelanjutan dengan memusatkan focus yang lain, sebab dalam penelitian ini masih banyak kekurangan dan keterbatasan

\section{DAFTAR PUSTAKA}

Depdiknas. (2001). Kamus Besar Bahasa Indonesia. Jakarta: Balai Pustaka.

Fattah, N. (2004). Prinsip-prinsip Manajemen. Jakarta: Bina Aksara.

Haris, A., \& Nuryanti. (2010). Psikologi dalam Pendidikan. Bandung: Alfabeta.

Husaini, U. (2009). Metodologi Penelitian Sosial. Jakarta: Bumi Aksara.

Moleong, L. (2002). Metodologi Penelitian Kualitatif. Bandung: PT Remaja Rosdakarya.

Mulyono. (2010). Konsep pembiayaan pendidikan (Kedua). Yogyakarta: ArRuzz Media.

Saefullah. (2012). Manajemen Pendidikan Islam. Bandung: CV. Pustaka Setia.

Schein, E. H. (2008). Organizational Culture and Leadership. San Francisco: JosseyBass.

Soejipto. (1992). Administrasi Pendidikan. Jakarta.

Sulistyorini. (2009). Evaluasi Pendidikan Dalam Meningkatkan Mutu Pendidikan. Yogyakarta: TERAS.

Supriadi, D. (2010). Satuan Biaya Pendidikan Dasar dan Menengah. Bandung: PT Remaja Rosdakarya.

Suryobroto. (2004). Manajemen Pendidikan di Sekolah. Jakarta: Rineka Cipta.

Terry, G. R. (2005). Dasar-Dasar Manajemen. Jakarta: PT. Bumi Aksara.

Wijayanti, I. D. S. (2008). Manajemen. (A. Setiawan, Ed.). Yogyakarta: PT Remaja Rosdakarya. 